\title{
Język a kultura. Komunikacja werbalna w wybranych polskich, brytyjskich i amerykańskich programach telewizyjnych
}

\author{
Language and culture. Verbal communication in selected \\ Polish, British and American TV programmes
}

\author{
Anna Zięba \\ Instytut Językoznawstwa, Uniwersytet im. Adama Mickiewicza \\ al. Niepodległości 4, 61-874 Poznań \\ azieba@amu.edu.pl
}

\begin{abstract}
This article is an attempt to analyze culture's impact on human verbal communication. The first part combines the differences between Polish and English with the cultural dimensions described by Geert Hofstede and with Hall's contextuality. Then, actual examples of verbal manifestations of cultural differences are given based on popular Polish, British and American TV programmes. These are talk shows: Rozmowy $w$ toku and The Oprah Winfrey Show, dancing shows: Taniec z gwiazdami and Strictly Come Dancing, and medical dramas: $\mathrm{Na}$ dobre $i$ na zte and Emergency Room. The source material on which this paper is based consists of recordings of the shows (recorded while broadcast and a Warner Bros DVD), a video sharing website YouTube and literature concerning cultural differences and their impact on language.
\end{abstract}

\section{Wstęp}

Od parudziesięciu lat obserwujemy zjawisko globalizacji, rozwój techniki zbliża ludzi do siebie, między innymi dzięki Internetowi kontakty międzykulturowe są coraz częstsze. Znajdujemy się w sytuacji współistnienia, w sytuacji, w której możemy korzystać z tego, co w kulturach świata najlepsze: z wzajemnych doświadczeń.

Kluczem do sprawnej komunikacji międzykulturowej jest zrozumienie różnic kulturowych, które dzielą narody świata. Ze względu na to, iż język jest odbiciem kultury jego użytkowników, każdy język posiada cechy charakterystyczne dla kultury, w której jest używany (Humboldt 2001, Sapir 1921). Komunikujemy się głównie za pomocą języka, tak więc aby zrozumieć interlokutora i wyrazić swoje myśli w sposób dla niego zrozumiały, konieczne jest rozpoznanie werbalnych manifestacji różnic kulturowych. W niniejszym artykule porównana zostanie komunikacja $\mathrm{w}$ polskich, brytyjskich i amerykańskich programach telewizyjnych. Podane zostaną również przykłady konkretnych zachowań językowych charakterystycznych dla danej kultury. 
Abyśmy mogli mówić o różnicach kulturowych, potrzebny jest pewien punkt odniesienia, podział kultur, postawienie pewnych cech charakterystycznych dla jednej kultury w opozycji do innych. Przywołajmy więc wymiary kultury podane przez Geerta Hofstedego (2000), holenderskiego socjologa. Dzieli on kultury na indywidualistyczne, kolektywistyczne, kobiece, męskie, kultury o różnym dystansie władzy i stopniu unikania niepewności. Czym jednak charakteryzuje się język używany przez osoby identyfikowane $\mathrm{z}$ daną kulturą?

\section{Język a kultura - wymiary (Geert Hofstede)}

W krajach o małym dystansie władzy komunikujące się osoby nie podkreślają wyższości żadnej ze stron. Partnerskie układy w rodzinie, szkole czy pracy, mają swoje odbicie w sposobie komunikacji osób wychowanych w tych krajach. Dzieci często mówią do rodziców po imieniu; w szkole, gdy czegoś nie rozumieją, pytają. Pracownicy nie maja problemu ze zwracaniem się do przełożonych (ibid.: 67). Są to kraje, gdzie sprzeciw osoby znajdującej się niżej w hierarchii jest dopuszczalny.

W krajach o dużym dystansie władzy sytuacja jest odwrotna: w komunikacji podkreślana jest pozycja rozmówców, miejsce w hierarchii, które zajmują. Dzieci raczej nie odzywają się nieproszone. Również w szkole to nauczyciel zazwyczaj inicjuje rozmowę. Pracownicy posłusznie wykonują polecenia przełożonego. Sprzeciw osoby znajdującej się niżej $\mathrm{w}$ hierarchii nie jest dopuszczalny. Ważną rolę pełnią zwroty grzecznościowe i tytuły.

Dla krajów indywidualistycznych charakterystyczna jest komunikacja bezpośrednia; rozmówcy utrzymują dystans. Ceni się szczerość, nie unika bezpośredniej konfrontacji, można odmówić spełnienia prośby, nie przyjąć zaproszenia. W szkole dopuszcza się dyskusję między uczniem a nauczycielem. Mówi się o swoich planach, swoich przeżyciach, wyraża się swoje opinie.

W krajach kolektywistycznych porozumiewamy się zazwyczaj w kategoriach „my”/,oni”. W kulturze tej ważne jest zachowanie pozorów, poczucie przynależności do grupy, jednolite (w grupie) poglądy. Spełnienia prośby raczej się nie odmawia, przyjmuje się zaproszenia (choć nie zawsze $\mathrm{z}$ nich korzysta). W szkole, w trakcie lekcji, uczeń częściej rozmawia z kolegami niż z nauczycielem.

Komunikacja w krajach kobiecych charakteryzuje się pewnego rodzaju „miękkością”, rozmówcy zawsze mają na uwadze utrzymanie dobrych stosunków, nie chcą sprawić nikomu przykrości. Rzadko dochodzi do kłótni, konflikty rozwiązuje się pokojowo, na drodze kompromisu. Mówi się raczej cicho niż głośno, często używa się zdrobnień. Ceni się tu skromność, a normą jest przeciętność. Komplementy nie są zbyt częste, tak jak i pochwały.

W krajach męskich komunikacja służy nie do podtrzymywania więzi międzyludzkich, a do wymiany informacji. Rozmowy są głośniejsze niż w krajach kobiecych, wypowiadane sądy ostrzejsze, więcej używa się też przekleństw, nie stroni się od awantur.

W krajach o niskim unikaniu niepewności zazwyczaj rozmawia się na przyjemne tematy, rozmówcy robią wrażenie zadowolonych z życia, panuje tu duża swoboda $\mathrm{w}$ sposobie mówienia. Szkolne podręczniki, jak i książki naukowe pisane są dość prostym, przystępnym językiem. Nauczyciel nie musi znać odpowiedzi na każde zadane przez ucznia pytanie. Od przełożonych nie wymaga się precyzyjnych instrukcji.

W krajach o wysokim poziomie unikania niepewności dużo się narzeka, częstym tematem rozmów jest zdrowie, a dokładniej: problemy zdrowotne. Rozmówcy robią wrażenie niezadowolonych $\mathrm{z}$ życia. Unikanie niepewności wiąże się $\mathrm{z}$ unikaniem dwuznaczności. Oznacza to czasem wywołanie kłótni tylko po to, żeby zmierzyć się z 
nieznanym $\mathrm{i}$ w ten sposób zredukować niepokój. Co ciekawe, rozmowy często przypominają kłótnie, nawet kiedy nimi nie są. W rozmowie używa się bowiem podniesionego tonu, mówi głośno. Osoby wychowane w kulturze wysokiego unikania niepewności mają ściśle sprecyzowane oczekiwania wobec rozmówcy i jeśli współrozmówca ich nie spełni, trudno jest im się odnaleźć w zaistniałej sytuacji. Szkolne podręczniki, jak i książki naukowe pisane są zazwyczaj skomplikowanym, naukowym językiem, ponieważ uważa się, że im tekst jest trudniejszy do zrozumienia, tym mądrzejszy. Nauczyciel powinien znać odpowiedź na każde zadane przez ucznia pytanie. Od przełożonych wymaga się precyzyjnych poleceń. W krajach o dużym unikaniu niepewności panuje zamiłowanie do teoretyzowania, tak więc często rozmowy prowadzone są na tematy filozoficzne, popularne jest tzw. ,gdybanie”.

\section{Kontekstowość (Edward T. Hall)}

Inny uczony, amerykański etnolog i antropolog, Edward T. Hall (2001) podzielił kultury na wysokokontekstowe i niskokontekstowe. Według Halla, na sposób porozumiewania się ludzi wpływa kontekst, czyli okoliczności towarzyszące sytuacji komunikacyjnej. Kontekst oznaczać mogą wcześniejsze zdarzenia, rozmowy uczestników komunikacji, typ zachowania przyjęty w danej kulturze. Hall użył słowa kontekstowanie do określenia procesu poznania, podkreślając wagę znaczenia kontekstu w przekazie znaczenia wypowiedzi.

W komunikacji wysokokontekstowej ważna jest forma komunikacji, szczególnie niewerbalna. Uczestnicy komunikacji dzielą tę samą wiedzę, poglądy, wyznają te same wartości. $Z$ tego powodu ważne jest często to, co nie zostało powiedziane, bo powiedziane być nie musiało, ponieważ słuchacz wie, o czym jest mowa. Osobom z kultury niskokontekstowej wydawać się może więc, że rozmowa w wysokim kontekście do niczego nie prowadzi. W komunikacji wysokokontekstowej istotne są m.in. gesty, ton głosu i mimika. Ceni się harmonię i subtelność wypowiedzi. Informacje przekazywane są nie wprost i nie bezpośrednio. Interakcja jest bardziej formalna, znaczenie ma pozycja, reputacja, wiek i status rozmówców. Od słuchacza oczekuje się wiedzy na poruszany temat, zrozumienia oraz poprawnych reakcji. Nietaktem jest prosić o wythumaczenie. Ponadto dla słuchacza dodatkowe tłumaczenie może być nawet obraźliwe.

Komunikacja niskokontekstowa to komunikacja, w której to wypowiedzi są głównym nośnikiem informacji. Informacje przekazują słowa, ich znaczenie jest nadrzędne względem tonu głosu, mimiki czy gestykulacji. W wypowiedzi zawarte jest całe przesłanie, niewiele powiedziane jest „w domyśle”. Komunikacja cechuje się bezpośredniością, celowością i jasnością. Ceni się zwięzłość, jednoznaczność i skuteczność wypowiedzi. Ważne są umiejętności wysławiania się, zdolność dokładnego przekazania szczegółowych informacji. Od słuchacza oczekuje się uwagi, potwierdzenia zrozumienia lub ewentualnie prośby o uściślenie znaczenia. Osoby wychowane w systemie niskiego kontekstu wkładają wiele starań w to, aby użyte przez nie słowa jak najlepiej oddawały to, co chcą przekazać. Słowa traktowane są dosłownie. Język charakteryzuje się linearnością, odzwierciedla on dedukcyjny tok myślenia. Interakcja jest mniej formalna w porównaniu z kulturą wysokokontekstową. Pozycja, reputacja, wiek czy status rozmówców nie mają aż tak dużego znaczenia. Rozmówcy mają tendencję do udowadniania innym swoich racji, nie unikają drażliwych tematów. Bezpośrednia odmowa spełnienia prośby czy wykonania polecenia jest czymś naturalnym. Polecenia są bezpośrednie i szczegółowe. Słowo „nie” nie jest słowem niegrzecznym. 


\section{Język polski a język angielski}

Przedstawiwszy cechy charakterystyczne dla języków różnych kultur, przejdźmy teraz do porównania komunikacji w języku polskim i języku angielskim na podstawie programów telewizyjnych produkcji polskiej, brytyjskiej i amerykańskiej. Na ich przykładzie zostanie pokazane, jak duży wpływ na sposób komunikacji w danym kraju ma jego kultura. Wybrane programy to polski talk show Rozmowy w toku prowadzony przez Ewę Drzyzgę i amerykański talk show The Oprah Winfrey Show prowadzony przez Oprah Winfrey, programy rozrywkowe: polski Taniec z gwiazdami i jego pierwowzór, brytyjskie Strictly Come Dancing oraz seriale telewizyjne o tematyce medycznej: polskie Na dobre i na złe i amerykańskie Emergency Room (Ostry dyżur). Porównując dialogi w polskich, brytyjskich i amerykańskich programach, skupimy się na zachowaniach werbalnych interlokutorów i przedstawimy manifestacje różnic kulturowych w języku polskim i języku angielskim. Najpierw jednak postarajmy się przybliżyć cechy charakterystyczne tych języków.

Z wyników badań przeprowadzonych przez Geerta Hofstedego (WWW 19.04.2007) w latach 2001 - 2003 wynika, że Polska jest krajem o umiarkowanym dystansie władzy, lekko indywidualistycznym, raczej męskim, dość silnie unikającym niepewności. Język polski uznawany jest za wysokokontekstowy.

Cechą świadczącą o tym, że jest to kraj o umiarkowanym dystansie władzy jest to, że używa się tu wielu tytułów i to $\mathrm{w}$ połączeniu $\mathrm{z}$ formą pan/pani/państwo: pan doktor, pani profesor, pan dyrektor, a nawet pan dozorca, pani sprzątaczka. Forma ty używana jest wśród osób młodych, będących w bliskich stosunkach. Od wieku i stopnia zażyłości zależy również to, jak się witamy: dzień dobry bądź cześćc, hej. Na tabliczkach informacyjnych prośby wyrażane są w formie nakazu lub zakazu: Nie palić, Szatnia obowiazkowa. Zwracanie komuś uwagi nie jest Polakom obce.

To, że jest to kraj męski, widać po tym, że Polacy często są chwaleni przez innych. Samemu jednak chwalić się nie wypada. W komunikacji miejskiej czy w tłumie rzadko słyszy się słowo przepraszam z ust przepychających się osób. Język polski obfituje w przekleństwa, które usłyszeć można prawie wszędzie, choć takie zachowanie wciąż jest uważane za niegrzeczne, szczególnie przez osoby starsze. Rozmówcy często się przerywa, rzadko pyta o zdanie, częściej wymienia się sądy na dowolny temat i jest to zazwyczaj krytyka. Poruszane tematy to polityka, problemy zdrowotne, problemy w pracy, sprawy osobiste. Mówi się dość głośno, wiec z daleka rozmowy te wyglądać mogą jak kłótnie.

Ogólne polskie narzekanie spowodowane może być wysokim poziomem unikania niepewności. Wypowiedzenie się na temat tego, czego się boimy, co nas trapi, może być sposobem pokonywania niepokoju. Dyskusje i głośne zachowanie, o których wspomniano wyżej, również pomagają w radzeniu sobie z poczuciem zagrożenia.

Co ciekawe, $\mathrm{z}$ badań wynika, że Polska jest krajem trochę bardziej indywidualistycznym niż kolektywistycznym. Z przykładów podanych do tej pory można było wywnioskować, że jest to kraj kolektywistyczny. Polska przeszła przez ostatnie 20 lat wiele zmian politycznych i ekonomicznych, a co za tym idzie także społecznych. Pod uwagę należy wziąć to, że indywidualizmowi sprzyja wzrost gospodarczy, zamożność kraju (cf.: Hofstede 2000: 129 - 130). Tak więc rozwój Polski wpływa znacząco na zachowanie Polaków. Co więcej, są oni codziennie wystawieni na oddziaływanie kultury anglosaskiej: angielskie $\mathrm{i}$ amerykańskie piosenki $\mathrm{w}$ radiu, seriale $\mathrm{w}$ telewizji, filmy $\mathrm{w}$ kinie. Nawet nowe ,polskie” seriale komediowe Hela w opałach (Grace Under Fire: Grace $w$ opałach) i Niania (The Nanny: Pomoc domowa) sa adaptacjami seriali amerykańskich. 
Można zauważyć, że młode pokolenie Polaków operuje innym językiem niż osoby wychowane $\mathrm{w}$ Polsce sprzed stanu wojennego. Używa ono nie tylko nowych słów i zwrotów. Inne są reakcje i zachowania językowe. Młody Polak zmierza w kierunku indywidualizmu (Bokszański 2007), męskości i małego dystansu władzy.

Osoby ze starszego pokolenia, gdy częstują, rzadko przyjmują odmowę. Kiedy częstuje dwudziestolatek, nie ponawia prośby, a jeśli nawet się upewnia Na pewno? to przypomina to częste w angielskim Are you sure?. Młodzi nie pytają się Czego się napijesz?, tylko: Chcesz coś do picia?. W pracy, w zespole trzydziestolatków pracownicy mówią do siebie per „ty”. Na wiadomość o zdanym egzaminie rodzic, mimo iż dumny z córki czy syna, powie: Udalo ci się, No, to tadnie, gratuluję. Kolega powie: Super! No, gratulacje!. Wierzbicka (1991: 43 - 44) pisze, że w polskim dużo częściej niż w angielskim używa się wzmocnień: strasznie, bardzo, a z kolei w angielskim zwrotów wyrażających niepewność, „zmiękczających”: well, I mean, sort of. Przysłuchując się rozmowom dwudziestolatków, trudno nie zauważyć, jak często obok wzmocnień, używają oni zwrotów: noo, znaczy, tak jakby, coś na wzór. Wierzbicka (ibid.: 49 - 50) traktuje język polski jako język kolektywistyczny. Podkreśla, że Polacy, odnosząc się do Polski, identyfikują się z nią: nasza ojczyzna, nasz naród, natomiast Anglicy, Australijczycy czy Amerykanie swoją ojczyznę określają: this country, this nation. I znów: coraz rzadziej słyszy się z ust Polaków zwroty zacytowane przez Wierzbicką, a coraz częściej: $\boldsymbol{w}$ tym kraju, Polacy, Polska. Nawet słowo ojczyzna jest coraz rzadsze.

Stany Zjednoczone, jak i Wielka Brytania są natomiast krajami o małym dystansie władzy, krajami zdecydowanie indywidualistycznymi, dość męskimi, o słabym unikaniu niepewności (wyniki badań Geerta Hofstedego (WWW 19.04.2007)).

O małym dystansie władzy w tych krajach świadczyć mogą powitania (Hello do wszystkich, niezależnie od wieku czy stanowiska), brak zakazów na tabliczkach informacyjnych, nieużywanie tytułów czy traktowanie rozmówców jak równych sobie partnerów. Wyrażany w rozmowie szacunek dla odrębności jest też oznaką indywidualizmu. Przytoczyć tu można odwoływanie się do woli proszonej przez nas o coś osoby, symbolikę zapytania How are you? czy $I$ pisane wielką litera, występujące w rozmowie dużo częściej niż polskie ja.

Jest to kraj męski: dużo mówi się o pracy, chwali sukcesami, nawet samo określenie człowieka jako successful, (określenie niemające swojego odpowiednika w języku polskim: zwycięski?!) świadczy o jego wielkiej wartości. Brytyjczycy czy Amerykanie nie odczuwają większego niepokoju. Lubią niespodzianki, szybko przystosowują się do nowych sytuacji.

Język angielski jest językiem niskokontekstowym: bezpośrednim, jasnym. Ceni się fakty i zdaje z nich dokładną relację. Interlokutorzy starają się oddać rzeczywistość jak najwierniej. Myśli czy fakty przedstawiane są jedne po drugich. W kulturze anglosaskiej za słowami idą czyny, co widoczne jest w angielskich zwrotach: Practice what you preach, Do what you say, Walk the walk, talk the talk.

Aby uzasadnić wymienione powyżej cechy języka polskiego i języka angielskiego charakterystyczne dla nich w odniesieniu do wymiarów Hofstedego i kontekstowości Halla, przejdźmy do analizy wypowiedzi prowadzących, aktorów, dziennikarzy, jurorów oraz postaci serialowych występujących $w$ wybranych polskich, brytyjskich i amerykańskich programach telewizyjnych. 


\section{$5 \quad$ Rozmowy w toku ${ }^{1}$ i The Oprah Winfrey Show ${ }^{2}$}

W opisywanym odcinku Rozmów w toku pt. Życie prywatne znanych dziennikarek wystąpiły znane polskie dziennikarki: Katarzyna Kolenda-Zaleska, Grażyna Bukowska, Marta Grzywacz i Joanna Racewicz. Gośćmi programu byli również: dziennikarz Grzegorz Miecugow oraz trener medialny Joanna Luboń. W analizowanym odcinku The Oprah Winfrey Show pt. Finding Neverland Special: Johnny Depp and Kate Winslet Oprah rozmawia ze znanymi aktorami: Johnnym Deppem, Kate Winslet i Freddiem Highmorem odtwórcami głównych ról w filmie Finding Neverland (Marzyciel).

Różnice w komunikacji w obu kulturach, polskiej i amerykańskiej, widoczne są już w samej atmosferze panującej w studiach. Jak na niskokontekstową publiczność przystało, niemający problemu z wyrażaniem emocji Amerykanie, a tu właściwie Amerykanki, zachowują się głośno: krzycza, piszczą i klaszczą. Aplauz, jaki dostaje Johnny Depp, nie może się równać z brawami dla dziennikarek u Drzyzgi. W The Oprah Winfrey Show ton rozmowy jest luźny (yeah użyte 142 razy), u Drzyzgi bardziej formalny.

Kontekstowość wpływa też na sposób zadawania pytań: obie prezenterki zadają bezpośrednie pytania w prostej, krótkiej formie: A czemu stuży to ćwiczenie? Kasiu, a w czym ty jesteś ortem, jak twoja Ania odrabia lekcje? oraz: And how did you get discovered? Why? What do you love the most about her?. Pytania tego typu, charakterystyczne dla kultury niskiego kontekstu stanowią $86 \%$ pytań Winfrey i $56,5 \%$ pytań Drzyzgi. W kulturze wysokokontekstowej pytania nie muszą być zadane bezpośrednio. Do wypowiedzenia się na dany temat gość zachęcony może być słowami: Na co dzień sq zadania z matematyki... (koniec pytania), Trudno uwierzyć, ale pierwsze kroki w telewizorze, bo mówisz o tym bakcylu... polknęlaś ten bakcyl i pierwsze kroki stawialaś będąc mala dziewczynka... (koniec pytania). Takich pytań w programie Drzyzgi było $43,5 \%$, a w programie Winfrey: $11 \%$.

U Drzyzgi na pytanie zakończone partykułą pytajną wymagającą potwierdzenia Jaka progresywna postawa, nie?, które skierowane było do Bukowskiej, odpowiada nie tylko ona: Tak!, ale też Kolenda-Zaleska (wymownie): W tamtych czasach.... Wyraz nieżle użyty w dalszym wypowiedzeniu To zostato nieźle przyjęte charakterystyczny jest dla wielbiącej skromność komunikacji wysokokontekstowej.

W The Oprah Winfrey Show widoczna jest, tak charakterystyczna dla języków niskokontekstowych, potrzeba dosłowności, dbałość o to, aby użyte słowa jak najlepiej oddawały to, co mają przekazać: Winfrey: But they thought he was a little... what was the word they used? czy: Winfrey: Let's just think in terms of what, you know, sultriness is and sexy is, wouldn't you say that you are? Depp tak stara się wytłumaczyć swoją wcześniejszą wypowiedź, w której mówi, że Stany Zjednoczone są ,jak szczeniak” (puppy): What I said was, the United States of America is a young country compared to Europe, compared to, you know, other countries. We're young. We're 200 and something years old. [...] It's not very old. [...] We're not thousands and thousands years old. Wydaje się, że powtarza on pewne opinie, ponieważ chce je dobrze zdefiniować.

\footnotetext{
${ }^{1}$ Rozmowy w toku. Życie prywatne znanych dziennikarek. Prowadząca: Ewa Drzyzga. Producent: Ewa Leja. Emisja 5.03.2007, TVN. (nagrane w trakcie emisji)

${ }^{2}$ The Oprah Winfrey Show. Finding Neverland Special: Johnny Depp and Kate Winslet. Prowadząca: Oprah Winfrey. Producent: Harpo Productions. Serwis YouTube Broadcast Yourself, 9.07.2007: http://pl.youtube.com/watch?v=GKEgO4ppdng (part1), http://pl.youtube.com/watch? $=$ =sePjtyCIpOw\&mode=related\&search= (part 2), http://pl.youtube.com/watch?v=KvpNvzin4v8\&mode=related\&search $=($ part 3), http://pl.youtube.com/watch?v=y0msMX8PWPw\&mode=related\&search $=($ part 4), http://www.youtube.com/watch?v=UY3F fjxkns\&mode $=$ related\&search $=($ part 5).
} 
Oglądając The Oprah..., odnosi się wrażenie, że Winfrey ciągle się upewnia (Really? użyte 14 razy), czy właśnie o to, o czym powiedział rozmówca, mu chodziło, czy dobrze zrozumiała. Powtarza to, co mówią jej goście. Podtrzymuje w ten sposób rozmowę $\mathrm{i}$ możliwe, że celowo nie używa innych słów, które mogłyby zmienić znaczenie oryginalnej wypowiedzi. Depp: I saw her back. Winfrey: You saw her back? Depp: Oh boy! Winfrey: Oh boy?! Depp: Well, it might be interesting. Winfrey: It might be interesting... W języku polskim takie powtarzanie byłoby znakiem dla gościa, że mówi za cicho i prowadzący ledwie go słyszy lub, że powinien rozwinąc temat. U Winfrey tak jednak nie jest. Rozmówcy reagują na jej powtórzenia jedynie kiwnięciem głowy lub zdawkowym Yeah.

W wypowiedziach Deppa występuje pewna hasłowość. Tak mówi o swojej reakcji na złą interpretację jego słów jednej z gazet: 'Look, you know, the press is not representing me. Let me represent myself. Let me speak to you.' And they said, 'OK, what do you want to say?' I said it, told them what I meant by the comment, which was completely different than what was, you know, shot out into the public. And they said, 'OK, I understand. I understand your point of view now. I'm sorry.' Jego wypowiedź jest rytmiczna, obrazowa, trzyma widza w napięciu, choć jest jakby pocięta. Widać tu linearność języka angielskiego. Co więcej, te same zwroty, wypowiedziane po polsku, brzmiałyby głupio, ponieważ Polacy przyzwyczajeni są do wypowiedzi mniej dosadnych i bardziej złożonych; do wypowiedzi bez tak dużej ilości powtórzeń i cytatów. Dla nas im bardziej skomplikowany tekst, tym mądrzejszy. Innym przykładem „hasłowości” są słowa Winslet o porodzie jej syna: And then c-section, there you go!, a dalej: I had an epidural. Yeah. [...] I did. I was induced. And I did 15 hours with nothing and then I thought, OK, now, you know, I really am actually going to fall apart. So had the epidural and that meant that I... Winfrey: So you did 15 hours without the epidural? Winslet: Yeah. Winfrey: God bless you!. Jak widać temat rozmowy jest dość osobisty, jednak w bezpośrednich, niskokontekstowych i indywidualistycznych Stanach Zjednoczonych nikogo nie razi mówienie o rzeczach intymnych, w innych kulturach pewnie uważanych za zbyt intymne.

$\mathrm{Z}$ badań Hofstedego wynika, że obydwa interesujące nas $\mathrm{w}$ tej chwili kraje są krajami indywidualistycznymi, jednak nie w tym samym stopniu. W języku polskim widać również cechy kolektywistyczne. Kolenda-Zaleska mówi o czasie spędzonym ze swoją córką w liczbie mnogiej: My uwielbiamy razem robić projekty historyczne, ostatnio robilyśmy projekt: „Wycieczka po Krakowie”. Wiesz jaka to byla przyjemność dla nas? [...] Albo robilyśmy projekt: „Katedry gotyckie w Europie”. Uwielbiamy to robić. Drzyzga, zapraszając do studia gościa, używa zaimka w liczbie mnogiej: Zapraszam ją do nas!.

Do poprzedniego spotkania z Bukowską Drzyzga odnosi się: Wiesz, bo pewnie Pani oglądata nasze spotkanie, kiedy rozmawialyśmy... [Bukowska]: Poprzednie o dietach. Tak, tak. Winfrey wcześniejsze spotkanie z Deppem widzi z perspektywy swojej osoby: $\underline{\boldsymbol{I}}$ remember seeing you briefly on the red carpet at Oscars. Tam gdzie Winfrey rozpoczyna pytania: I heard Drzyzga używa bezosobowego: podobno.

Winfrey odnosi do swojej osoby również wiele pytań: Yeah. That's why I didn't believe the quote when I read it, because... [...] I've been misquoted a couple of times myself. [...] Yeah. So-and is it true-when I read this, I thought, I've done that myself. When I've been misquoted on something and it's been misrepresented, I will get on the phone and call the people. [...] Did you get on the phone and call the people?.

Drzyzga natomiast nie chce być w centrum uwagi. Kiedy Bukowska zadaje jej pytanie: Nie, nie, nie... Jak wiele ty otrzymujesz takich dowodów?, ona odpowiada: Nie, w ogóle... w ogóle to nie ma nic do rzeczy! Rozmawiamy o informacji! Marta... i kontynuuje zadawanie pytań gościom. 
Cechą amerykańskiego indywidualizmu jest przywiązywanie wielkiej wagi do osiągnięć, do sukcesu. Winfrey dosadnie podkreśla wyjątkowość swoich gości, zapowiadając ich, a następnie zwracając się do nich. O Deppie: sexiest man alive, his performance is just superb, one of the most gifted actors of his generation, do Winslet: Congratulations on such an amazing performance. It really is outstanding, you look spectacular.

W Rozmowach $w$ toku widoczny jest większy dystans władzy niż w The Oprah Winfrey Show. Na „ty” są tylko znające się osoby (Drzyzga z reguły mówi do swoich gości po imieniu), inni używają grzecznościowych pan/pani. Kolenda-Zaleska o występie w programie Mamy Cię!: Ale najgorsze jest to, że myśmy rano dużo rozmawiali na temat tego, jak będziemy wkręcać Pania Hannę Gronkiewicz-Waltz. Miecugow o trenerze medialnym i swoim koledze: Ale to Pani Joanna wlaśnie wyciagnęla tu przejęzyczenie Jarka Gugaly, który powiedzial „cztery glupie partie”, zamiast „cztery glówne partie”. W Rozmowach $w$ toku wyczuwa się specyficzną dla krajów o większym dystansie władzy formalność. U Winfrey rozmowa jest mniej formalna. Dużo się żartuje, Winfrey przedrzeźnia innych, zmienia ton głosu na męski, popijają wino, Depp żartuje: $\boldsymbol{O h}$, we're going to be drunk in a minute.

Duże unikanie niepewności widoczne jest w Rozmowach $w$ toku w sytuacjach innych niż codzienne, w sytuacjach niespodziewanych. Zaczyna się wtedy robić głośno, wiele osób mówi naraz.

Zarówno Drzyzga, jak i Winfrey poprosiły fanów swoich gości o zadanie im pytań. Zapowiedź owych pytań u Drzyzgi była bardziej formalna (jeszcze raz wysoki kontekst): Jeżeli już mówimy o sympatii, to postanowiliśmy zapytać waszych widzów o to... nie, nie, nie jak was oceniaja, tylko jakie pytania chcieliby oni wam zadać. Winfrey: When our viewers found out that Johnny was coming on the show we heard from many of your diehard fans. You know you've got some dieharders out there. They have their-Johnny! And they all have their own burning questions, burning questions they wanted to ask. First up, Catina wanted to know something personal, take a look. Same pytania też różniły się stopniem formalności. W Rozmowach w toku: Mam pytanie do Pani Joanny Racewicz, czy zgodzilaby się zaprosić na drinka?. Na tak nieoczekiwane i bezpośrednie pytanie Racewicz odpowiedziała zaskoczona i oburzona: Nie! [...] Ale w zadnym wypadku! [...] Nie, odpowiedź na to pytanie brzmi ja mam z kim pijać drinki. W The Oprah Winfrey Show pytanie zadane Deppowi brzmiało: Hi, Johnny. I think you are absolutely hot. I know you have a way of charming the ladies so I wanted to know what is the most romantic thing you've ever done on a date?. Pytanie nie zdziwiło adresata, spokojnie opowiedział o wynajętym przez niego niemym kinie i wzbudził zachwyt Żeńskiej publiczności.

\section{Taniec z gwiazdami ${ }^{3}$ i Strictly Come Dancing ${ }^{4}$}

$\mathrm{W}$ badaniach komunikacji $\mathrm{w}$ dwóch programach rozrywkowych o tematyce tanecznej, analizie poddane zostały pozytywne komentarze, jakie usłyszała polska para Katarzyna Cichopek i Marcin Hakiel oraz brytyjska para, Colin Jackson i Erin Boag, a następnie

\footnotetext{
${ }^{3}$ Taniec z gwiazdami. Reżyser: Wojciech Iwański. Producent: Agnieszka Koniecka, TVN Grupa ITI. Licencja BBC. Para: Katarzyna Cichopek i Marcin Hakiel: emisja 20.11.2005, TVN. Edycja 2, odc. 8. (nagrane w trakcie emisji). Para: Wojciech Majchrzak i Magdalena Soszyńska: emisja 11.03.2007, TVN. Edycja 5, odc. 2. (nagrane w trakcie emisji).

${ }^{4}$ Strictly Come Dancing. Reżyser: Alex Rudzinski. Producent: Format Entertainment (executive producer: Karen Smith). Serwis YouTube Broadcast Yourself. Para: Colin Jackson i Erin Boag: emisja 17.12.2005. Seria 3, finał. http://www.youtube.com/watch?v=j9B2IV9T8kA Para: Claire King i Brendan Cole: emisja 25.11.2006. Seria 4, 2 tydzień. http://www.youtube.com/watch?v=DP-XzRrHt54
} 
negatywne oceny, które otrzymali Wojciech Majchrzak i Magdalena Soszyńska (para polska), oraz Claire King i Brendan Cole (para brytyjska).

Pierwszą rzeczą, która rzuca się w oczy, jest płynność wypowiedzi Brytyjczyków w porównaniu $\mathrm{z}$ wypowiedziami Polaków. Wypowiedzi polskich sędziów często są przerywane. Wypowiedź Tyszkiewicz: Znaczy ja czuję, nie wiem jak wy. Przerywa Galiński: To byla piękna rumba, Pani Beato, i to widać byto. Mówią dalej, wchodząc sobie w słowo: Tyszkiewicz: No właśnie to chciałam powiedzieć. Galiński: Doskonale, doskonale, Pani Beato. Tyszkiewicz: Tylko ja się boję po prostu powiedzieć. Galiński: Bo to wplywa na charakter tańca, dobrze, kontynuujmy, Pani Beato, świetnie. Pavlović wchodzi w słowo Urbańskiemu, jakby sugerowała, że chce zabrać głos: Urbański: Kariera w dyplomacji. Pavlović: Ponieważ... Urbański: Już ja tam widzę. Pavlović: Ponieważ, ciekawa jestem, ponieważ... i kontynuuje wypowiedź. Świadczyć to może o niższym niż w Wielkiej Brytanii indywidualizmie, gdzie dyskutanci, żeby zabrać głos, czekają, aż osoba wypowiadająca się przed nimi skończy. Skutkiem takiego przerywania jest to, że wypowiedzi polskich jest więcej niż brytyjskich (28 do 17) mimo, iż różnica w czasie trwania fragmentów nie jest znacząca, a rozmówcy mówią mniej więcej w tym samym tempie: 2,5 wyrazu na sekundę. Oczywiście należy wziąć pod uwagę fakt, iż słowa polskie są dłuższe (średnio 5,2 znaku do 4,6 znaku), tak więc wypowiadane są szybciej. W Strictly Come Dancing wypowiedź każdego z sędziów zajęła w przybliżeniu taki sam czas - około 16 sekund, natomiast wypowiedzi polskich jurorów różniły się długością. Tyszkiewicz mówiła około 10 sekund, a Pavlović 32 sekundy.

Komentarze brytyjskich sędziów odnoszą się często bezpośrednio do nich samych bądź do tańczących: Whenever Colin vou come on the floor, you look like a dancer, you've never disappointed me, what you do very well, you complement your hips with your arms, you carry on the move and you finish it beautifully, Colin you have expressive arms. Polskie komentarze są raczej bezosobowe: No, byto pięknie, piękna praca bioder i piękna praca nóg, to była piękna rumba, no po prostu fantastycznie.

Treść wypowiedzi sędziów może wiele powiedzieć o kontekście w komunikacji w analizowanych fragmentach programów. W komentarzu w Tańcu z gwiazdami pada 28 wypowiedzi. Wiele $\mathrm{z}$ nich jest niedokończonych lub nie niesie treści bezpośrednio związanej z wypowiedzią wcześniejszą: Urbański: Prosze wyprzedzić cios, na co Tyszkiewicz odpowiada: A! Tego się boicie! No, było pięknie, ale... umiecie tańczyć ze soba, czuje się takie to uczucie, tak, tam... Również końcówka cytowanej wypowiedzi Tyszkiewicz (takie to uczucie, tak, tam) nie niesie treści sama w sobie. Tyszkiewicz odwołuje się do kontekstu, do zmysłowej rumby, którą przed chwilą tańczyli partnerzy. Tyszkiewicz nie nazywa uczucia. Prawdopodobnie dlatego, że wszyscy taniec widzieli i wiedzą, jaki on był. W takiej sytuacji w Strictly Come Dancing sędziowie odwołują się do konkretnej cechy tańca. Używają wielu przymiotników: fabulous, beautiful, musical, lovely, smouldering, hot, passionate, expressive, sensual. Co więcej, na 28 wypowiedzi polskich sędziów aż $13 \mathrm{z}$ nich nie dotyczyło oceny tańca: Ja... Ja myślę, aż się boję. Jak to ode mnie tak zacząć? Ja jestem przyzwyczajona zawsze, żeby się przeciwstawić Iwonce. No, to ja czekam... Proszę wyprzedzić cios. Tylko ja się boję po prostu powiedzieć. Na 17 wypowiedzi sędziów brytyjskich wszystkie bezpośrednio dotyczyły wystąpienia pary. Pierwszy dłuższy komentarz w Tańcu z gwiazdami (ponad 10 wyrazów) Pavlović dała dopiero w 70 sekundzie analizowanej części programu. Sędziowie brytyjscy komentowali od drugiej sekundy. Jak widać, polskim jurorom więcej czasu zabrały rozmowy o niczym.

Zapytana w innej kolejności niż zazwyczaj Tyszkiewicz, odpowiada Ja... Ja myśle, aż się boję. Jak to ode mnie tak zacząć?. Jako osoba wychowana w kraju o wysokim poziomie unikania niepewności nie czuje się komfortowo w nowej sytuacji. 
O większym dystansie władzy w Polsce niż w Wielkiej Brytanii świadczyć może np. to, że zarówno Urbański, jak i Pavlović i Galiński do znajomej im, starszej osoby, Beaty Tyszkiewicz, zwracają się Pani Beato. Tyszkiewicz natomiast, zwraca się do młodszej Pavlović po imieniu.

Przejdźmy teraz do komentarzy negatywnie oceniających pozostałe pary. Krytyka sędziów brytyjskich jest dużo bardziej agresywna. Zarówno sędziowie, jak i jeden $\mathrm{z}$ uczestników mówią podniesionym głosem, wręcz krzyczą: What are you doing this for?!. Mówią wtedy dużo szybciej: Phillips 3,4 wyrazu na sekundę, Cole aż 3,9 wyrazu na sekundę. Tak jak przy ocenie pozytywnej, i tu komentarz odnosi się bezpośrednio do osoby ocenianej: You've got a screw loose! You ruined something, that could have been great!. Odnosimy więc wrażenie, że słowa wymierzone są w konkretne osoby. Krytyka jest bardziej osobista. Phillips wręcz osądza tancerza: And you just never learn your lesson!, a wypowiedź swoją kończy groźbą: You see, when you get your scores!. Ostrość tych wypowiedzi może mieć związek z niskim kontekstem, ponieważ komunikacja niskokontekstowa cechuje się bezpośredniością, celowością i jasnością. W krajach takich, jak Wielka Brytania ceni się zwięzłość, jednoznaczność i skuteczność wypowiedzi. Agresja wyrażana jest też werbalnie w krajach męskich o niskim dystansie władzy.

Co ciekawe, krytyka dotyczy nie gwiazdy, ale zawodowego tancerza. I to nie gwiazda, a tancerz odpiera ataki jury. W jego słowach widoczny jest niski dystans władzy Wielkiej Brytanii: You know, it... Arlene, it... Bruno, it doesn't matter! Because you say it ruined routine. It didn't ruin the routine. It was a fantastical routine with this fantastical woman. Mark me down, it doesn't matter! Taka odpowiedź w Polsce nie byłaby dobrze przyjęta. W kraju o wyższym dystansie władzy nie wypada sprzeciwiać się sędziemu, a już na pewno nie można zwrócić się do niego Mark me down, it doesn't matter!, ponieważ oznaczałoby to brak szacunku dla jurora.

W Tańcu z gwiazdami krytyka wyrażana jest bardzo grzecznie, łagodnym tonem. Jurorzy nie przyspieszają, a nawet lekko zwalniają: mówią średnio 2,3 wyrazu na sekundę. Jest w większości bezosobowa: Byta bardzo sztywna góra. Dotyczy ona jedynie gwiazdy, która przyjmuje złe słowa $\mathrm{z}$ pokora, $\mathrm{w}$ milczeniu. Pavlović mówi o prawidłowym wykonaniu tańca: Ale tu zaczęlam od góry, bo góra tak naprawdę jest refleksem tego co się dzieje $w$ dole. Jeżeli odpowiednia jest akcja bioder, to $i$ wtedy góra też zaczyna delikatnie tańczyć, aby zakończyć: Przyznaję, że tego nie byto. Jej wypowiedź nie jest ostra: Nazwalabym tak: nie zatańczyleś rumby, ale tadnie przespacerowaleś się w rytmie rumby. Tak łagodna krytyka charakterystyczna jest dla krajów wysokokontekstowych, gdzie ceni się harmonię i subtelność wypowiedzi. Informacje przekazywane są nie wprost i niebezpośrednio, a interakcja jest bardziej formalna. O wysokim kontekście świadczyć mogą też inne wypowiedzi: Zbyszku, dajmy szansę... Ja mam swoje kontakty. No.

Ciekawe jest to, że w analizowanym odcinku Tańca $z$ gwiazdami zarówno prowadzący, jak i pozostali sędziowie mówią o Tyszkiewicz, używając jej imienia: to chyba Beata ci podsunęla te źródta, Trochę ci się podoba ten Pan, prawda? (do Tyszkiewicz). Jest to jednak odcinek piątej edycji polskiego tanecznego show, więc możliwe, że po tak długiej znajomości, osoby te przeszły na „ty”. Mówiąc o ocenianym Majchrzaku, zwracając się do niego, używają formy grzecznościowej „pan”: Szalenie Pan jest stremowany, zeszczuplat Pan, może niech Pan mniej tańczy, strasznie jest Pan tym pochtonięty.

Tak jak przy pozytywnej ocenie i teraz wypowiedzi polskich jurorów różniły się długością. Pavlović mówiła przez 24 sekundy, a Tyszkiewicz przez 40 sekund. Sędziowie i prowadzący dalej wchodzili sobie w słowo, przerywali. Gdy Pavlović zaczynała mówić: No, może tokcie tak, ale Wojtku.... Urbański przerywał: Nie mówilem?. Pavlović 
kontynuowała: Byta bardzo sztywna góra. W innym miejscu Tyszkiewicz: Poza tym Pan jest przystojny. Na co Pavlović: A !. Tyszkiewicz mówiła dalej: Zgrabny. Urbański wtrącił: Trochę ci się podoba ten Pan, prawda?. Tyszkiewicz: No i co z tego?. Urbański: No, jak co z tego?.

\section{$7 \quad$ Na dobre i na z te $^{5}$ i Emergency Room ${ }^{6}$}

Analizowane odcinki wymienionych seriali to Pioruński pech (189) oraz Such sweet sorrow (134). W obu odcinkach znalazły się sceny, w których personel szpitala ratuje nieprzytomnego chorego oraz sceny rozmów lekarza z pacjentem bądź pacjentami. Te właśnie sceny posłużyły nam jako materiał badawczy.

\subsection{Akcja ratownicza poza szpitalem}

Najbardziej widoczną różnicą między $N a$ dobre $i$ na złe oraz $E R$ jest ilość terminów medycznych używanych przez personel. W polskim serialu lekarz pogotowia zadaje pytania ludziom zgromadzonym wokół porażonego przez piorun mężczyzny dotyczące tego, co się stało, kiedy i kim on jest: Czy ktoś go zna? Wie Pan, gdzie on mieszka? Nie? A Pani nie wie, jak on się nazywa?. Lekarz nie wymienia badań, które powinny zostać zrobione, nie mówi nic na temat stanu poszkodowanego, nie rozmawia $\mathrm{z}$ ratownikami. Dopiero po przybyciu do szpitala lekarz pogotowia opisuje stan pacjenta drugiemu lekarzowi: Pacjent po reanimacji. Ciśnienie 80/50, tętno niemiarowe okolo 105 na minutę, źrenice reaguja na światto, podano mu dekstran. W amerykańskim serialu natomiast, personel medyczny toczy żywą dyskusję na temat stanu kobiety, która straciła przytomność przed wejściem na izbę przyjęć. Stażystka wydaje dyspozycje pielęgniarkom i pielęgniarzom odnośnie do ich zadań: She needs a couple of large-pore IVs. 2 litters of saline wide open, mix up dopamine, get an ultrasound. Jak widać, używa ona wielu terminów medycznych. Co ciekawe, pielęgniarki biorą czynny udział w diagnozowaniu: Maybe it's an ectopic - sugeruje jedna z nich, co dla stażystki jest czymś naturalnym. W obydwu serialach osoba o wyższym statusie decyduje o przeniesieniu pacjenta na nosze, lecz innymi słowami: Let's get her on a gurney i Zabieramy go na nosze.

\subsection{Akcja ratownicza w szpitalu}

W ER personel mówi dużo więcej i znacznie szybciej: 3 wyrazy na sekundę w porównaniu do 0,8 wyrazu na sekundę w Na dobre i na złe. Ciekawe jest to, że w polskim serialu w akcji ratowniczej nie biorą udziału pielęgniarki. W amerykańskim natomiast stanowią oni (jest również pielęgniarz) większość personelu ratującego pacjentkę. Tak jak w poprzednim fragmencie i tu pada wiele terminów medycznych, bo ponad 15: dopamine, Hemacue, adnexa, mass of free fluid, Tube Ovarian Abcess, septic, loculated mass, infection, syncopal episode, hemorrhagic ovarian cyst, hypotensive, we fragmencie $\mathrm{Na}$ dobre i na złe tylko 4. W amerykańskim serialu pielęgniarka dopytuje stażystki o to, co ta zauważyła: What is it? na co stażystka tłumaczy: Tube Ovarian Abcess. When they rupture, they get septic and hypotensive. W polskim serialu lekarze niewiele $\mathrm{z}$ soba rozmawiaja, odzywają się do siebie półsłówkami, a mimo to sprawnie współdziałają. Nie pytają o wyniki, nie wymieniają wielu terminów medycznych. O konieczności wykonania badań widz dowiaduje się dopiero z późniejszej rozmowy lekarzy ze stażystką. Lekarz

\footnotetext{
${ }^{5}$ Na dobre i na złe. Piorunski pech (189). Reżyser: Krzysztof Rogala. Producent: Telewizja Polska - Telewizyjna Agencja Produkcji Teatralnej i Filmowej (dla Programu II TVP). Scenariusz: Ilona Łepkowska. Emisja 25.03.2007, TVP2. (nagrane w trakcie emisji)

${ }^{6}$ Emergency room (ER). Such sweet sorrow (134). Reżyser: Michael Crichton. Producent: Constant C Productions i Amblin Television we współpracy z Warner Bros Television Productions Inc.. Scenariusz: John Wells. Emisja 11.05.2000, NBC. (DVD - Producent: Warner Bros.)
} 
pyta: No. Co teraz robimy, Koleżanko?, stażystka odpowiada: Chyba powinniśmy zlecić badania laboratoryjne, żeby ocenić zaburzenia elektrolitowe $i$ metaboliczne. No $i$ gazometria. Lekarze nie są usatysfakcjonowani odpowiedzią: A rentgen, tomografia glowy, USG? pyta jeden. Drugi dodaje: No właśnie? Skąd pewność, że nie doszło do urazu glowy, kręgostupa albo obrażeń wewnętrznych?

Jedyne pytanie dotyczące stanu pacjenta zadane $\mathrm{w}$ trakcie akcji ratowniczej brzmi bardzo ogólnie: I jak? tak jak zresztą i odpowiedź na nie: Nic, no. Jeden z lekarzy pyta się drugiego o sens ich dalszego działania, upewnia się: Co, myślisz, że to ma sens?. Do sukcesu odnoszą się bezosobowo: No i udalo się.

\subsection{Rozmowa z pacjentem}

W ER zarówno lekarze, jak i pielęgniarze zwracają się do pacjentów i do siebie nawzajem przez "you": How long have you been experiencing the burning?, Weaver sent you a present - a wheezer, Are you sure?. W polskim serialu lekarz używa formy grzecznościowej „pan”, zwracając się do pacjenta: $\boldsymbol{A}$ co $\underline{\text { Pan pamięta?, Niech Pan }}$ odpoczywa. Przy badaniu prosi go o to, żeby poruszał rękoma, tak jak on. Swoją prośbę odnosi nie tylko do pacjenta, ale też do siebie: Ale otwieramy oczy. Otwieramy. Musimy się unieść troszkę, dobrze? I naciskamy. No to ktadziemy się. Lekarz uprzedza pacjenta co będzie badał: Zbadamy symetrię sity mięśniowej. Gdy pacjent wykonuje jego polecenia, ten wyraża aprobatę: Dobrze. W ER lekarz nie mówi, co będzie badał, ale za to komentuje badanie, mówi pacjentowi, co mu dolega.

Liczba terminów użytych przez personel szpitala zależeć może od wymiaru indywidualizmu/kolektywizmu. W kulturach indywidualistycznych pacjent traktowany jest bardziej przedmiotowo. Jest obiektem pracy lekarzy i pielęgniarek, a praca, jak wiadomo, jest w tej kulturze najważniejsza. Nie można również zapominać o tym, że analizowane sceny pochodzą z serialu telewizyjnego, czyli skonstruowane są tak, aby zaciekawić widza. W ER napięcie budowane jest wokół czynności wykonywanych przez personel medyczny szpitala. W Na dobre i na złe wokół więzi międzyludzkich. W polskim serialu ważniejsze jest to, że pacjent jest jednym z nas, jest człowiekiem. Każdy z nas mógłby znaleźć się w jego sytuacji. Napięcie budowane jest wokół emocji, które towarzyszą ratowaniu nieprzytomnej osoby. To, że pacjent traktowany jest jak osoba, a nie jak przedmiot badania, widać też w sytuacji, gdy lekarz uprzedza pacjenta, co będzie badał. Jego zdaniem jest to ważna dla pacjenta informacja. Odnosi się do badanej osoby. Lekarz w serialu amerykańskim za ważną informację uznaje diagnozę. Odnosi się do badania.

Inną kwestią jest to, że Amerykanie komunikują się w sposób niskokontekstowy, bezpośredni. Aby się sprawnie porozumiewać, muszą wypowiedzieć to, co dla osób wysokokontekstowych jest oczywiste. Polacy pytając $\boldsymbol{I}$ jak? pytają o konkretną rzecz. Stąd różnice w ilości wyrazów użytych w akcji ratowniczej w Na dobre i na złe (0,8 na sek.) i ER (3 na sek.).

Lekarze w polskim serialu nie mówią o stanie pacjenta przy nim. To, że konieczne jest wykonanie pewnych badań, sugerowane jest w późniejszej rozmowie ze stażystką. Tak samo jest z wynikami i dalszym postępowaniem. W ER mówi się o tym w trakcie akcji ratunkowej, w Na dobre i na złe później, w gabinecie lekarskim. Lekarz pyta: Zapoznata się Pani z wynikami?. Na co stażystka: Tak, Panie Doktorze. Proszę. [...] Gazometria wykazala kwasice metaboliczna, ale glikemia jest w porzqdku. Natomiast zbyt duży jest poziom potasu, ale to jest wynikiem reanimacji. Dalej stażystka odpowiada na pytanie o wnioski: Wnioski sq takie, że pacjent nie mial zawatu, a wszelkie zaburzenia rytmu byly spowodowane silnym impulsem elektrycznym i na pytanie o dalsze postępowanie: $\mathbf{N a}$ pewno tlen, na pewno płyny. No i dalsza diagnostyka ewentualnych obrażeń. Zachowanie to dotyczyć może wymiaru dystansu władzy. Polski widz w trakcie akcji skupić się może 
na relacjach międzyludzkich, a dopiero potem zaprezentowana jest mu wiedza lekarzy. Lekarz przedstawiony jest jako osoba znajdująca się wysoko w hierarchii, z pewnością wyżej niż stażystka, która pełni rolę uczennicy, podwładnej. Być może z tego samego powodu lekarz w karetce nie rozmawia $\mathrm{z}$ ratownikami. Rolę ucznia przyjmuje też pacjent, który po wykonaniu polecenia lekarza jest chwalony (Dobrze). W ER nie tylko stażystka, ale również pielęgniarki traktowane są na równi z lekarzami: one sugerują diagnozę, lekarz thumaczy im, co pacjentowi dolega. Ponadto różnice między serialami w wymiarze dystansu władzy widoczne są w sposobie zwracania się do siebie pracowników szpitala i pacjentów (pan/pani i you).

Wracając do wymiaru indywidualizm/kolektywizm: oglądając $N a$ dobre $i$ na złe, trudno nie zauważyć, że Polacy są bliżej kolektywizmu niż Amerykanie. Świadczyć o tym może chociażby to, że lekarz, badając pacjenta, zwraca się do niego w liczbie mnogiej (wspomniane wcześniej Ale otwieramy oczy itd.). Lekarz po udanej reanimacji nie przypisuje sukcesu sobie ani drugiemu lekarzowi (No $\boldsymbol{i}$ udało się). Decyzja lekarza pogotowia o zabraniu pacjenta na nosze (Zabieramy go na nosze) wyrażona jest w liczbie mnogiej. Lekarka decyduje za wszystkich. Amerykańska stażystka w takiej sytuacji nie czuje się upoważniona do wydawania dyrektyw, mówi więc bardziej bezosobowo (Let's get her on a gurney). To, że decyzje odnoszą się do wspólnych działań, widoczne jest również w sytuacji, gdy jeden z lekarzy decyduje się na zastosowanie defibrylacji o mocy 300. Drugi lekarz pyta wtedy: Co, myślisz, że to ma sens?.

\section{Recepta na sprawną komunikację międzykulturową}

Przy porównaniu komunikacji w polskich, brytyjskich i amerykańskich programach telewizyjnych przedstawionych zostało wiele werbalnych manifestacji różnic kulturowych. Pod tym względem programy polskojęzyczne nie różnią się zbytnio między sobą, tak jak programy anglojęzyczne. Zachowania werbalne polskich dziennikarek, personelu medycznego oraz sędziów przejawiają te same bądź zbliżone cechy charakterystyczne dla kultury polskiej, natomiast zachowania werbalne gwiazd filmu, Oprah, personelu medycznego ER oraz brytyjskich jurorów charakterystyczne są dla kultury anglosaskiej. Przedstawione przykłady przejawów cech charakterystycznych dla danej kultury dowodzą, że język używany w danej kulturze jest przez nią ukształtowany.

Komunikacja międzykulturowa wymaga wiele cierpliwości i ciagłej świadomości różnic. XXI wiek stawia przed nami nowe wyzwania, zapomnieć należałoby o negatywnym nastawieniu do inności, o tym, że wróg zewnętrzny był zawsze najbardziej skutecznym sposobem na zachowanie wewnętrznej spójności (Hofstede 2000: 303). Ważne jest otwarcie się, poznawanie innych kultur i korzystanie $\mathrm{z}$ tego, co w nich najlepsze. Zaznajomienie się $\mathrm{z}$ innymi kulturami może nam pomóc nie tylko $\mathrm{w}$ komunikacji. Konfrontując nasze wartości z obcymi, możemy uzmysłowić sobie, w czym tkwią nasze mocne i słabe strony. Możemy pracować nad sobą i uczyć się od innych.

Omawiany temat będzie $\mathrm{z}$ pewnością nadal bardzo aktualny ze względu na rozwój kontaktów międzykulturowych. Zmiany, które są wynikiem tego rozwoju, napawać mogą obawą. Kultura jest jednak czymś tak w nas zakorzenionym, że nie należy bać się, że w wyniku globalizacji stracimy swoją tożsamość kulturową. Zmiany, które przechodzi na przykład język polski, nie są wynikiem amerykanizacji polskiego społeczeństwa, ale gospodarczego rozwoju kraju. Wszystko na świecie ewoluuje, zmian nie można zatrzymać, można jedynie zadbać o to, aby szły one w dobrym kierunku: wzajemnego porozumienia, szacunku i współpracy. 
Anna Zięba: Język a kultura. Komunikacja werbalna $w$ wybranych

polskich, brytyjskich i amerykańskich programach telewizyjnych

\section{Bibliografia}

I Opracowania książkowe

Bokszański, Z. 2007. Indywidualizm a zmiana społeczna. Wydawnictwo Naukowe PWN.

Hall, E., T. 2001. Poza kultura [Beyond culture]. Tłum. Elżbieta Goździak. Wydawnictwo Naukowe PWN, Warszawa.

Hofstede, G. 2000. Kultury i organizacje. Zaprogramowanie umystu [Cultures and organizations : software of the mind]. Tłum. Durska, M. Polskie Wydawnictwo Ekonomiczne, Warszawa.

Humboldt, W. 2001. Rozmaitość języków a rozwój umystowy ludzkości. Wydawnictwo KUL, Lublin.

Sapir, E. 1921. Language: An introduction to the study of speech. New York: Harcourt, Brace and company.

Wierzbicka, A. 1991. Cross-Cultural Pragmatics The Semantics of Human Interaction. Mouton de Gruyter, Berlin, Nowy Jork, s. 25 - 65.

II Źródła internetowe

Cultural Dimensions, Poland. Geert Hofstede ${ }^{\mathrm{TM}}$ Cultural Dimensions. 19.04.2007, http://www.geert-hofstede.com/hofstede poland.shtml

Cultural Dimensions, United Kingdom. Geert Hofstede ${ }^{\text {TM }}$ Cultural Dimensions. 19.04.2007, http://www.geert-hofstede.com/hofstede united kingdom.shtml

Cultural Dimensions, United States. Geert Hofstede ${ }^{\mathrm{TM}}$ Cultural Dimensions. 19.04.2007, http://www.geert-hofstede.com/hofstede united states.shtml

III Inne źródła

Rozmowy w toku. Życie prywatne znanych dziennikarek. Prowadząca: Ewa Drzyzga. Producent: Ewa Leja. Emisja 5.03.2007, TVN. (nagrane w trakcie emisji)

The Oprah Winfrey Show. Finding Neverland Special: Johnny Depp and Kate Winslet. Prowadząca: Oprah Winfrey. Producent: Harpo Productions. Serwis YouTube Broadcast Yourself, 9.07.2007: http://pl.youtube.com/watch?v=GKEgO4ppdng (part1), http://pl.youtube.com/watch?v=sePjtyCIpOw\&mode=related\&search= (part 2), http://pl.youtube.com/watch?v=KvpNvzin4v8\&mode=related\&search= (part 3), http://pl.youtube.com/watch?v=y0msMX8PWPw\&mode=related\&search= (part 4), http://www.youtube.com/watch?v=UY3F fjxkns\&mode=related\&search= (part 5).

Taniec z gwiazdami. Reżyser: Wojciech Iwański. Producent: Agnieszka Koniecka, TVN Grupa ITI. Licencja BBC. Para: Katarzyna Cichopek i Marcin Hakiel. Emisja 20.11.2005, TVN. Edycja 2, odc. 8. (nagrane w trakcie emisji) Para: Wojciech Majchrzak i Magdalena Soszyńska. Emisja 11.03.2007, TVN. Edycja 5, odc. 2. (nagrane w trakcie emisji)

Strictly Come Dancing. Reżyser: Alex Rudzinski. Producent: Format Entertainment (Karen Smith - executive producer). Serwis YouTube Broadcast Yourself:

Para: Colin Jackson i Erin Boag. Emisja 17.12.2005. Seria 3, finał.

http://www.youtube.com/watch?v=j9B2IV9T8kA

Para: Claire King i Brendan Cole. Emisja 25.11.2006. Seria 4, 2 tydzień. http://www.youtube.com/watch?v=DP-XzRrHt54

Na dobre i na złe. Pioruński pech (189). Reżyser: Krzysztof Rogala. Producent: Telewizja Polska - Telewizyjna Agencja Produkcji Teatralnej i Filmowej (dla Programu II TVP). Scenariusz: Ilona Łepkowska. Emisja 25.03.2007, TVP2. (nagrane w trakcie emisji)

Emergency room (ER). Such sweet sorrow (134). Reżyser: Michael Crichton. Producent: Constant C Productions i Amblin Television we współpracy z Warner Bros Television Productions Inc.. Scenariusz: John Wells. Emisja 11.05.2000, NBC. (DVD - Producent: Warner Bros.). 